\title{
Expression of epithelial membrane antigen and cytokeratin among Indian workers exposed to cotton fibre dust in textile industries
}

\author{
Ashish Mehta, ${ }^{1,2,3}$ Saud Azam, ${ }^{2,3}$ Arshad Rahmani, ${ }^{2,3}$ Moshahid Rizvi² and Ashish Mandal ${ }^{3}$
}

${ }^{1}$ Department of Pharmacology, Vardhman Mahavir Medical College and Safdarjung Hospital, New Delhi, India (Correspondence to: A. Mehta: bio. ashish@gmail.com). ${ }^{2}$ Department of Biosciences, Jamia Millia Islamia, New Delhi, India. ${ }^{3}$ Department of Pathology, Maulana Azad Medical College, New Delhi, India.

\begin{abstract}
Background: In India, around 20 million workers are engaged in the textile industries. However, the prevalence of byssinosis has been little reported.

Aims: To determine the prevalence of byssinosis and other respiratory disorders among workers exposed to cotton dust in textile mills in Delhi, India.

Methods: Sputum samples were collected from 156 workers employed in 15 cotton textile mills, and expression of epithelial membrane antigen (EMA) and cytokeratin (CK) marker proteins was investigated. Information regarding respiratory symptoms, certain personal characteristics and occupational history was also gathered.

Results: Symptoms were observed in $56.41 \%$ of the workers. Expression of EMA and CK was observed in $27.5 \%$ and $50 \%$ of the workers, respectively. Expression of EMA and CK was significantly associated with smoking and duration of employment.

Conclusion: Measures are needed to reduce dust levels in the workplace, and to discourage smoking and alcohol consumption a mong the textile workers.

Keywords: byssinosis, cotton dust, occupational health hazard, epithelial membrane antigen, cytokeratin, textile

Citation: Mehta A; Azam S; Rahmani A; Rizvi M; Mandal A. Expression of epithelial membrane antigen and cytokeratin among Indian workers exposed to cotton fibre dust in textile industries. East Mediterr Health J. 2022;28(2):152-157. https://doi.org/10.26719/emhj.21.058

Received: 26/11/20; accepted: 15/06/21

Copyright (C) World Health Organization (WHO) 2022. Open Access. Some rights reserved. This work is available under the CC BY-NC-SA 3.0 IGO license (https://creativecommons.org/licenses/by-nc-sa/3.0/igo)
\end{abstract}

\section{Introduction}

People with mild byssinosis have a "Monday feeling" of chest tightness and shortness of breath on the first day of work after a weekend or holiday. As exposure continues, this feeling persists throughout the week, and in advanced stages, byssinosis causes chronic, irreversible obstructive lung disease. Although cotton is by far the most common cause - accounting for such conditions as cotton-dust asthma and cotton-mill fever - flax, hemp and other organic fibres can also produce byssinosis. In India, an estimated 20 million workers are occupationally exposed to cotton dust in textile manufacturing industries (1). Previous studies have assessed the association between the duration of employment and the emergence of respiratory symptoms, and have reported longitudinal changes in the pulmonary function test as annual decline in lung capacity, in addition to chest tightness, chronic bronchitis, and chronic cough, and sharp decline in forced expiratory volume in one second (2). Earlier studies have reported prevalence rates of byssinosis of approximately $30 \%$ in Indonesia, 37\% in Sudan, 40\% in Ethiopia, up to $50 \%$ in India, $18 \%$ in Cameroon, $14.2 \%$ in Turkey, $6.2 \%$ in France, $5.9 \%$ in Greece, $5 \%$ in Slivakia, and $1.7 \%$ in the Czech Republic (3-9). The present study was, therefore, aimed at reporting the prevalence of byssinosis and other respiratory disorders among workers exposed to cotton dust in textile mills situated in Delhi, India.

\section{Methods}

The study participants exposed to cotton dust in textile stitching units in Delhi, India, were selected using a simple random sampling technique. We enrolled 156 workers employed in these units, and their detailed history was recorded using a predesigned questionnaire, after which they provided sputum samples. The workers were asked to take a deep breath and cough hard to spit into a plastic cup that was later disposed according to the biomedical waste regulations. All procedures performed in the study involving human participants were in accordance with the 1964 Declaration of Helsinki and its later a mendments or comparable ethical standards.

Paraffin blocks of the sputum samples were made as described previously (10). Sections ( $5 \mu \mathrm{m}$ thick) of the paraffin blocks were cut using a microtome, and stained with immunohistochemical molecular markers for epithelial membrane antigen (EMA) or cytokeratin (CK). Immunohistochemistry involved removal of the paraffin wax from the sections (10). Following this, antigen retrieval was performed using a microwave method (11). This used citrate buffer to expose the hidden antibody-binding sites. EMA marker protein (monoclonal antibody) was applied to the sections, and incubated overnight in a moist chamber at $4^{\circ} \mathrm{C}$ On the next day, the sections were washed in phosphate-buffered saline (PBS), secondary antibody was applied for 20 minutes, 
and the sections were kept at room temperature in a moist chamber. The sections were washed again in PBS, and tertiary antibody was a pplied for 20 minutes at room temperature in a moist chamber. This process increased the magnitude of the antibody-antigen reaction. The sections were washed one more time with PBS after 20 minutes. Diaminobenzidine was applied for staining of the cell nuclei. The same procedure was followed for measuring expression of cytokeratin (CK), by replacing EMA with CK, and using different sections of the same samples.

EpiData version 3.1 was used for quality data capture, and for univariate and bivariate analysis. The $\chi^{2}$ test was used to measure the association between categorical variables. Multivariate logistic regression analysis of the different factorsfor EMA and CK wasestimated, stratified by age, smoking or alcohol consumption status, duration of smoking or alcohol consumption, or employment. J < 0.05 was considered statistically significant.

\section{Results}

A total of 156 workers in 15 different textile stitching industries were surveyed: 150 men and 6 women; age range $16-60$ years, median age 27 years. The mean duration of employment in the current section was 9.8 years, and the mean salary was INR 2881 . The socioeconomic status of the workers was also recorded, and the number of workers earning (per month) in the range of INR 1000-2000, 2000-3000, 3000-4000 and 4000-5000 was 33, 74, 37 and 12 , respectively.

The prevalence of respiratory disorders among workers was found to be $56.41 \%$ [ $95 \%$ confidence interval (CI): 45.24-69.50\%]. All workers provided individual history and answered a detailed questionnaire focused on the diagnosis of respiratory disorders. The incidence was: chest pain (10.89\%), chronic bronchitis (10.25\%), tuberculosis $(5.77 \%)$, back pain $(5.12 \%)$, cough $(4.48 \%)$, chronic productive cough (3.84\%), insomnia $(3.20 \%)$, and difficulty in breathing $(1.28 \%$ ) (Table 1 ).

Figure 1 shows the association between the number of smokers or drinkers and their economic status.

\begin{tabular}{|c|c|c|}
\hline Symptoms/diseases & $\begin{array}{l}\text { No. of } \\
\text { individuals }\end{array}$ & Prevalence (\%) \\
\hline Chest pain & 17 & 10.89 \\
\hline Cough & 7 & 4.48 \\
\hline Chronic bronchitis & 16 & 10.25 \\
\hline Chronic productive cough & 6 & 3.84 \\
\hline Difficulty in breathing & 2 & 1.28 \\
\hline Insomnia & 5 & 3.20 \\
\hline Pain in back bone & 8 & 5.12 \\
\hline Tuberculosis & 9 & 5.77 \\
\hline Others & 18 & 11.54 \\
\hline
\end{tabular}

Figure 2 shows the duration of smoking or drinking. There was a significant association between smoking and economic status $(J<0.01)$. The overall incidence of symptoms/diseases in textile stitching workers who had never smoked was $<5 \%$. About $82 \%$ of the workers had never consumed alcohol. Most of the workers had been employed in the textile stitching industries for the last 5-10 years (Figure 3). The prevalence of symptoms such as chronic bronchitis, chest tightness, and chronic productive cough was more common among smokers and drinkers. There was a significant association between the duration of employment and prevalence of respiratory symptoms $(J<0.05)$.

Epithelial membrane antigen (EMA) expression was observed in $27.5 \%$ (95\% CI: $19.48-37.87 \%$ ) of the textile workers. The percentage of positive cells ranged from $40 \%$ to $50 \%$, and the mean percentage positivity was $45 \%$ (Figure 4B). Logistic regression analysis revealed a significant association between EMA with smoking and its duration, alcohol consumption, and employment $(J=0.0001,0.02,0.02,0.0002$, respectively; Table 2). Expression of CK was observed in 50\% (95\% CI: 39.83$60.17 \%$ ) of textile workers. The percentage of positive cells ranged from $38 \%$ to $60 \%$, and the mean percentage positivity was $50.6 \%$ (Figure $4 \mathrm{C}$ ). Logistic regression analysis revealed a significant association between CK and smoking and duration of employment $(J=0.003$ and 0.0001 , respectively; Table 2 ).

\section{Discussion}

The findings of the present study are restricted to workers employed in textile stitching industries. There were fewer female workers and the age of the workers ranged from 16 to 60 years. Men within the 15-25 years age group were more sensitive to these respiratory symptoms. Smoking and alcohol consumption played a major role in causing symptoms/diseases including chronic bronchitis, chest tightness, cough, back pain, and breathing difficulty. The effect of this along with the textile environment has been reported to be additive (12). Most workers were from the Muslim community $(82.05 \%)$, so habitual alcohol consumption was mostly absent, but those who consumed alcohol showed symptoms/diseases. It has been reported that with the increased duration of exposure, the prevalence of byssinosis also increases (5). Moreover, symptoms such as chronic bronchitis, chest tightness, and chronic productive cough have been observed to be more prevalent among smokers than to nonsmokers (13). Several studies have identified bacterial endotoxin in cotton dust as the main causative agent contributing to adverse respiratory effects $(14,15)$. A 20year follow-up cohort study performed on workers in cotton textile mills in Shanghai, China, showed that the chronic loss of lung function was significantly associated with exposure to endotoxin rather than cotton dust (2).

Proinflammatory cytokines act as stimuli for the activation of immune cells, as well as the release of further cytokines and chemokines, and their cellular 
Figure 1 Association between number of workers with smoking or drinking habits and their monthly earning capacity

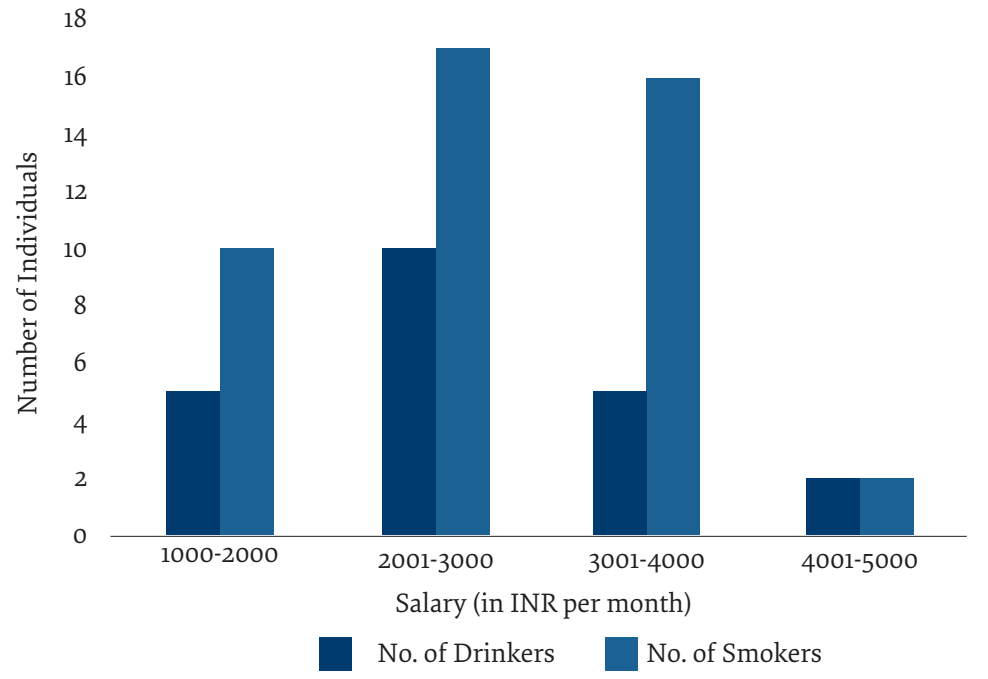

Figure 2 Duration of smoking or drinking habits of the workers

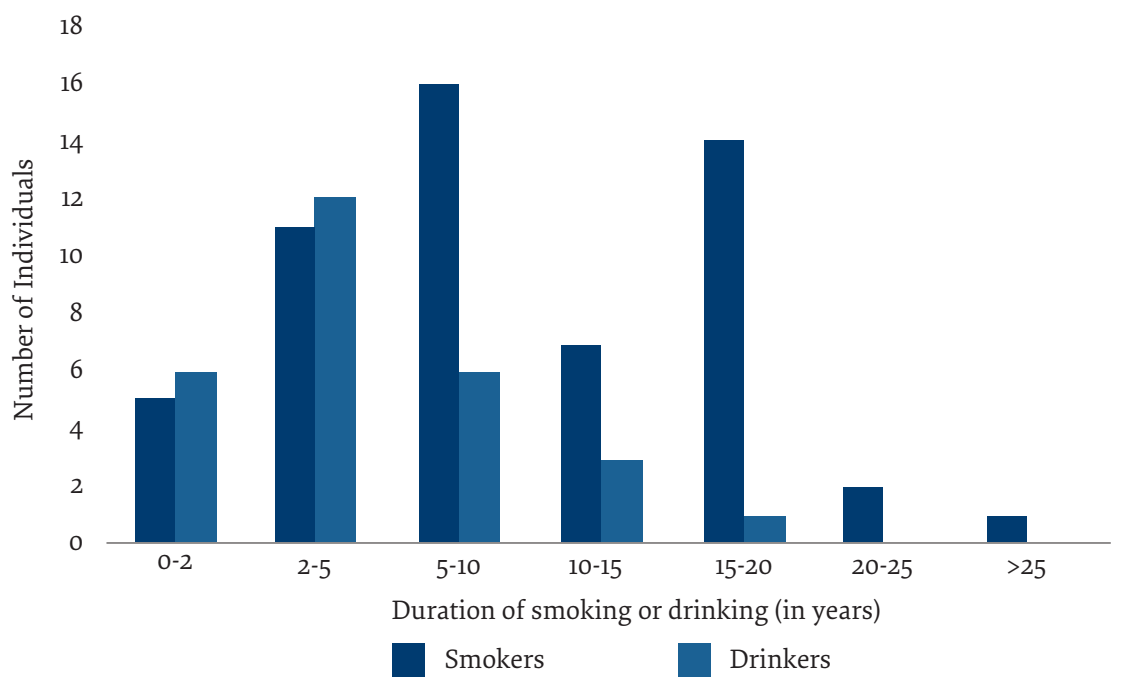

Figure 3 Duration of working of the individuals in the textile stitching industries

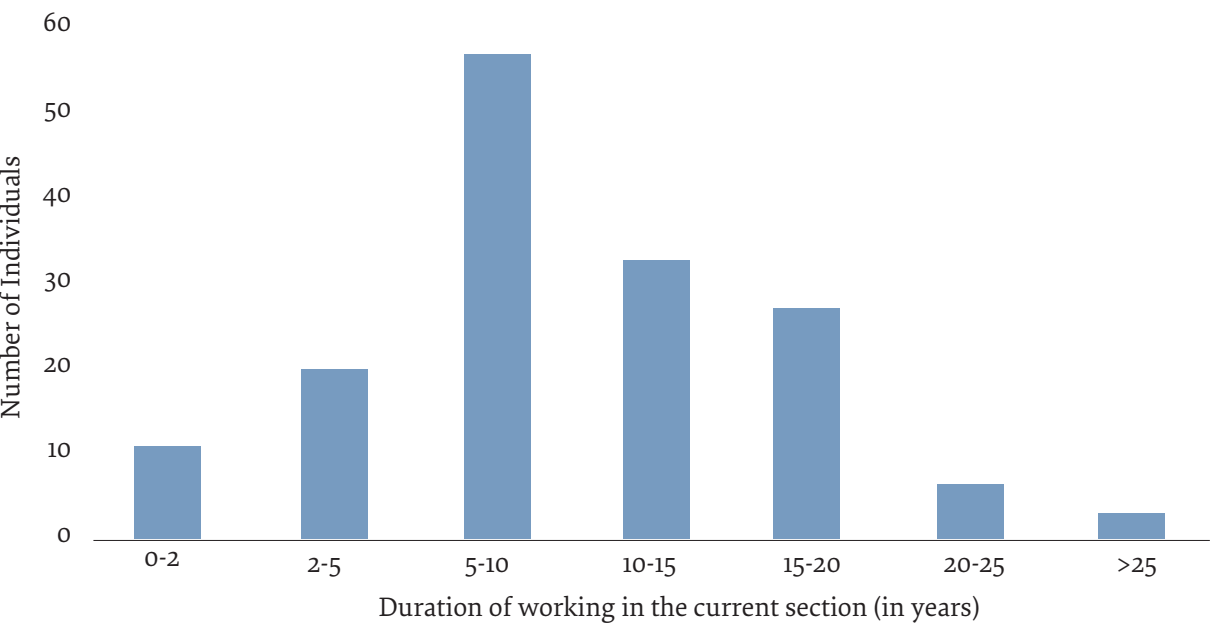


Figure 4 Expression of different immunological markers in sections of sputum blocks of (A) normal healthy, (B) EMA-positive and (C) CK-positive individuals

A

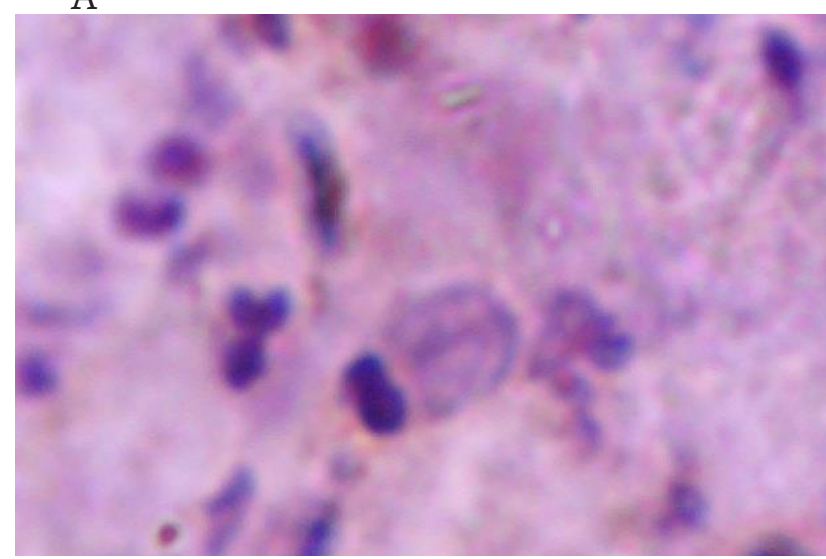

B

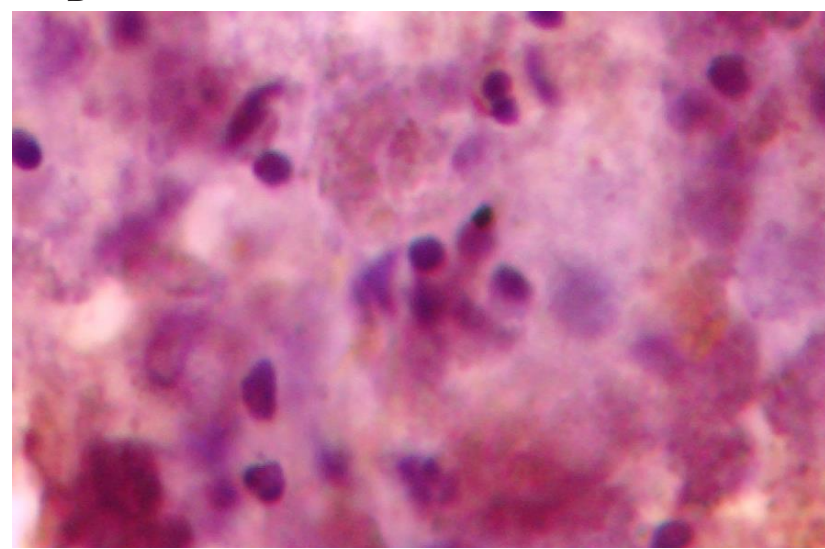

C

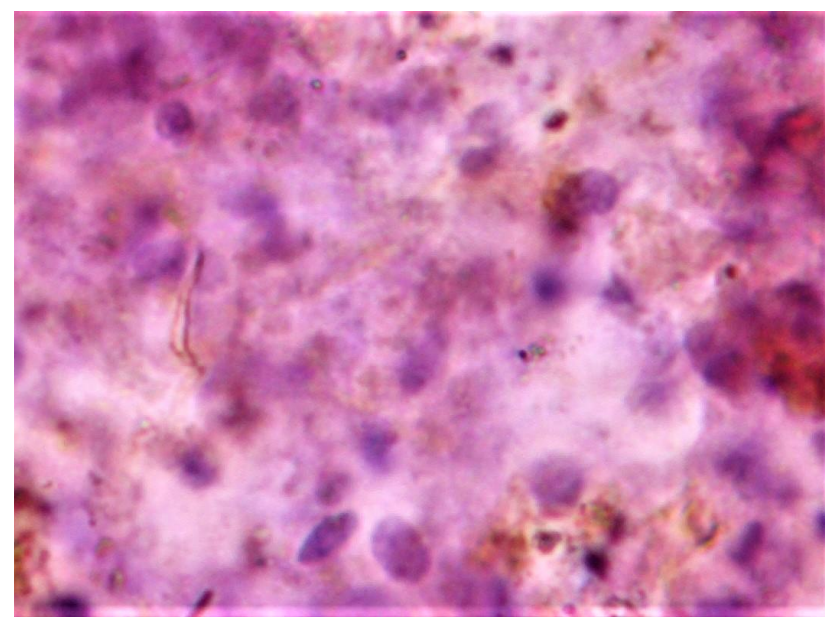

recruitment in bronchial epithelial cells (16). An earlier study has demonstrated that reactive oxygen species may have a role in the pathogenesis of airway inflammation and asthma (17). Eosinophils and neutrophils are characteristic features of asthma and allergic respiratory diseases (18). Acute exposure to cotton dust is reported to result in increased leukocyte count (19).

In the present study, immunohistochemistry was performed with EMA monoclonal antibody. EMA is useful for classifying tumours of epithelial origin and is included in the group of antibodies directed against leukocyte common antigen. A similar pattern of staining is seen in other glandular epithelia, such as sweat glands, while squamous epithelium shows an uneven pattern of antigen expression. Expression of EMA was observed in $27.5 \%$ of textile workers. The percentage of positive cells ranged from $40 \%$ to $50 \%$, and the mean percentage positivity was $45 \%$.

$\mathrm{CK}$ is the major structural protein of bronchial epithelial cells. Several studies have suggested that CKs

\begin{tabular}{|c|c|c|}
\hline Variable & $\begin{array}{c}\text { EMA } \\
\text { OR }(95 \% \text { CI }), P\end{array}$ & $\begin{array}{c}\text { CK } \\
\text { OR }(95 \% \text { CI), P }\end{array}$ \\
\hline Age & $0.87(0.45-1.67), 0.679$ & $1.00(0.63-1.61), 0.971$ \\
\hline Smokers & $15.59(4.04-60.09), 0.0001$ & $5.54(1.73-17.67), 0.003$ \\
\hline Alcohol consumption & $5.50(1.16-26.07), 0.031$ & $1.84(0.57-5.97), 0.304$ \\
\hline Duration of smoking & $6.44(1.21-34.04), 0.028$ & 4.14 (0.81-20.95), 0.085 \\
\hline Duration of alcohol consumption & $3.51(0.22-55.22), 0.371$ & $3.23(0.33-31.10), 0.309$ \\
\hline Duration of employment & $10.01(2.94-34.0), 0.0002$ & $9.53(4.01-22.65), 0.0001$ \\
\hline
\end{tabular}

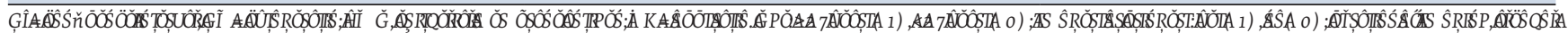

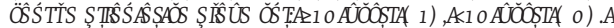


are proteolysed during apoptosis and can leak into the circulation as a soluble form, where they may serve as new epitopes for antibody generation (20-2 2$)$.

In the present study, $50 \%$ of cases were CK positive. CK is a cytoplasmic protein; therefore, monoclonal antibody binds to the antigen, leading to its expression. We ran a positive control and a normal control. The purpose of the positive control was to verify the staining procedure. CK expression in the normal control was $10 \%$; however, in the workers, it ranged from 38 to $60 \%$. Hence, it can be interpreted that cotton dust somehow influenced cell signalling, and this led to higher expression of CK.

Multivariate logistic regression analysis of the risk factors for EMA and CK revealed that their expression was associated with smoking, alcohol consumption, and duration of smoking or employment. Moreover, EMA and
CK expression was more significantly linked to smoking and duration of employment. Earlier studies have reported that smoking and duration of employment have a significant impact on workers employed in spinning mills, and coke oven workers exposed to polycyclic aromatic hydrocarbons $(13,23,24)$.

In conclusion, the present study suggests the need for implementation of protective measures such as installation of hoods, dust filters, ventilators, general cleanliness, and other safety measures, such as the use of dust masks, to reduce the risks of respiratory problems. In addition, training on safety measures, health education and welfare programmes should be organized for textile industry workers.

\section{Funding: None}

Competing interests: None declared.

\section{Expression de l'antigène de la membrane épithéliale et de la cytokératine chez les travailleurs indiens exposés à la poussière de fibres de coton dans les industries textiles}

\section{Résumé}

Contexte : En Inde, près de 20 millions de personnes travaillent dans les industries textiles. Cependant, la prévalence de la byssinose a été peu signalée.

Objectifs : Déterminer la prévalence de la byssinose et d'autres troubles respiratoires chez les travailleurs exposés à la poussière de coton dans les usines textiles de Delhi (Inde).

Méthodes: Des échantillons d'expectorations ont été recueillis auprès de 156 travailleurs dans 15 usines textiles de coton, et l'expression des protéines marqueurs de l'antigène de la membrane épithéliale et de la cytokératine a été étudiée. Des informations concernant les symptômes respiratoires, certaines caractéristiques personnelles et les antécédents professionnels ont également été collectées.

Résultats : Des symptômes ont été observés chez 56,41\% des travailleurs. L'expression de l'antigène de la membrane épithéliale et de la cytokératine a été observée chez $27,5 \%$ et $50 \%$ des travailleurs, respectivement. Celle-ci était fortement associée au tabagisme et à la durée d'emploi.

Conclusion: Des mesures sont nécessaires pour réduire les niveaux de poussière sur le lieu de travail, et afin de décourager le tabagisme et la consommation d'alcool parmi les travailleurs du textile.

$$
\begin{aligned}
& \text { الدليل على المستضدات الغشائية الظهارية والكيراتينات الخلوية بين العمال المنود المعرضين لغبار الألياف القطنية في } \\
& \text { صناعات النسيج }
\end{aligned}
$$

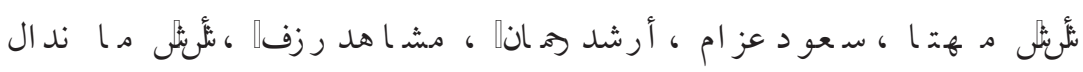

$$
\begin{aligned}
& \text { الخلاصة }
\end{aligned}
$$

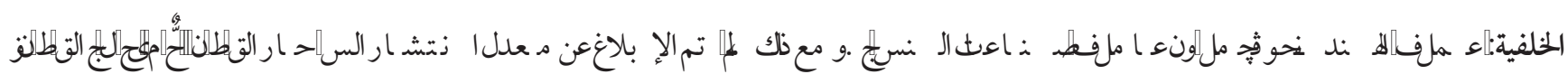

$$
\begin{aligned}
& \text { إلا قلهـ }
\end{aligned}
$$

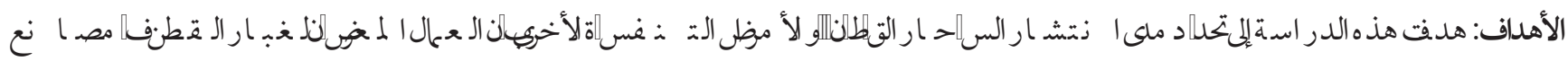

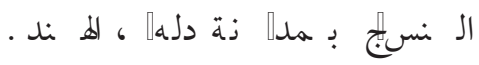

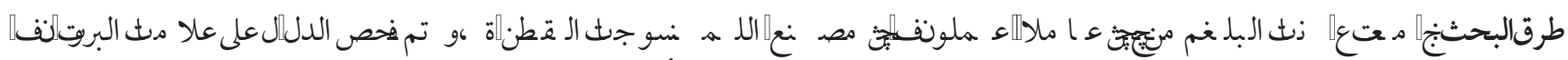

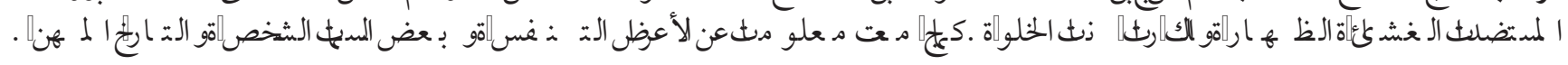

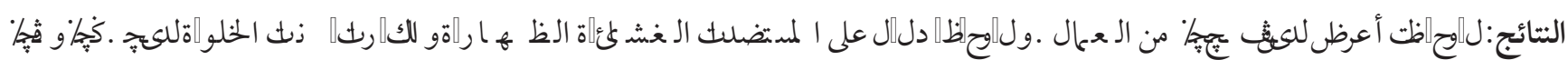

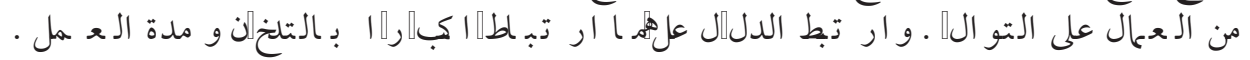

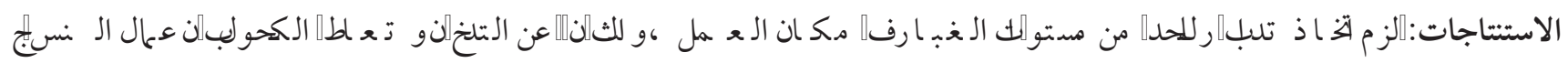




\section{References}

1. Mishra AK, Rotti SB, Sahai A, Madanmohan, Narayan KA. Byssinosis among male textile workers in Pondicherry: a case-control study. Natl Med J India. 2003 Mar-Apr;16(2):70-3. PMID:12816184

2. Wang XR, Zhang HX, Sun BX, Dai HL, Hang JQ, Eisan EA, et al. A 20-year follow-up study on chronic respiratory effects of exposure to cotton dust. Eur Respir J. 2005 Nov;26(5):881-6. https://doi.org/10.1183/09031936.05.00125604 PMID:16264050

3. Baratawidjaja K. Byssinosis study among 250 textile mill workers in Jakarta. Am J Ind Med. 1990;17(1):71-2. https://doi. org/10.1002/ajim.4700170117 PMID:2305795

4. El-Karim MA, Sharief N el-D and Ballal MA. Effects of exposure to cotton dust on energy expenditure in the textile industry. Int Arch Occup Environ Health. 1987;59(4):347-53. https://doi.org/10.1007/BF00405278 PMID:3610334

5. Abebe Y, Seboxa T. Byssinosis and other respiratory disorders a mong textile mill workers in Bahr Dar (North West Ethiopia). Ethiop Med J. 1995 Jan;33(1):37-49. PMID:7895745

6. Nakládalová M. Byssinosis. Acta Univ Palacki Olomuc Fac Med. 2000;143:43-6. PMID:11144117

7. Massin N, Moulin JJ, Wild P, Meyer-Bisch C, Mur JM. A study of the prevalence of a cute respiratory disorders a mong workers in the textile industry. Int Arch Occup Environ Health. 1991;62(8):555-6o. https://doi.org/10.1007/BFo0381108 PMID:1856010

8. Boubopoulos NJ, Constandinidis TC, Froudarakis ME, Bouros D. Reduction in cotton dust concentration does not totally eliminate respiratory health hazards: the Greek study. Toxicol Ind Health. 2010 Nov;26(10):701-7. https://doi. org/10.1177/0748233710377773 PMID:20639277

9. Takam J, Nemery B. Byssinosis in a textile factory in Cameroon: a preliminary study. Br J Ind Med. 1988 Dec;45(12):803-9. https://doi.org/10.1136/oem.45.12.803 PMID:3219305

10. Rahmani A, Alzohairy M, Khadri H, Rizvi MA, Mandal A. Paraffin sections of sputum block: description of a new method for pathological and molecular study. J Adv Medicine Med Res. 2011;1(3):141-5.

11. Shi S-R, Cote RJ, Wu L, Liu C, Datar R, Shi Y, et al. (2002). DNA extraction from archival formalin fixed, paraffin-embedded tissue sections based on the antigen retrieval principle: heating under the influence of pH. J Histochem Cytochem. 2002 Aug;50(8):1005-11. https://doi.org/10.1177/002215540205000802 PMID:12133903

12. Beck GJ, Schachter EN and Maunder LR. The relationship of respiratory symptoms and lung function loss in cotton textile workers. Am Rev Respir Dis. 1984 Jul;130(1):6-11. https://doi.org/10.1164/arrd.1984.130.1.6 PMID:6742614

13. Su YM, Su JR, Sheu JY, Loh CH, Liou SH. Additive effect of smoking and cotton dust exposure on respiratory symptoms and pulmonary function of cotton textile workers. Ind Health. 2003 Apr;41(2):109-15. https://doi.org/10.2486/indhealth.41.109 PMID:12725471

14. Christiani DC, Wang XR, Pan LD, Zhang HX, Sun BX, Dai HL, et al. Longitudinal changes in pulmonary function and respiratory symptoms in cotton textile workers. A 15-yr follow-up study. Am J Resp Crit Care Med. 2001;163:847-53. https://doi.org/10.1164/ ajrccm.163.4.2006063 PMID:11282755

15. Kennedy SM, Christiani DC, Eisen EA, Wegman DH, Greaves IA, Olenchock SA, et al. Cotton dust and endotoxin exposure-response relationships in cotton textile workers. Am Rev Respir Dis. 1987 Jan;135(1):194-200. https://doi.org/10.1164/ arrd.1987.135.1.194 PMID:3800146

16. Boulet LP, Lemiere C, Gautrin D, Cartier A. New insights into occupational asthma. Curr Opin Allergy Clin Immunol. 2007 Feb;7(1):96-101. https://doi.org/10.1097/ACI.obo13e328013ccd8 PMID:17218818

17. Folkerts G, Kloek J, Muijsers RB, Nijkamp FP. Reactive nitrogen and oxygen species in airway inflammation. Eur J Pharmacol. 2001 Oct 19;429(1-3):251-62. https://doi.org/10.1016/s0014-2999(01)01324-3 PMID:11698045

18. Wardlaw AJ, Brightling C, Green R, Woltmann G. Pavord I. Eosinophils in asthma and other allergic diseases. Br Med Bull. 2000;56(4):985-1003. https://doi.org/10.1258/0007142001903490 PMID:11359633

19. Holness DL, Taraschuk IG, Goldstein RS. Acute exposure to cotton dust a case of mill fever. JAMA. 1982 Mar 19;247(11):1602-3. PMID:7062465

20. Leers MP, Kolgen W, Bjorklund V, Bergman T, Tribbick G, Persson B, et al. Immunocytochemical detection and mapping of a cytokeratin 18 neo-epitope exposed during early apoptosis. J Pathol. 1999 Apr;187(5):567-72. https://doi.org/10.1002/(SICI)10969896(199904)187:5<567::AID-PATH288>3.0.CO;2-J PMID:10398123

21. Nahm DH, Lee YE, Yim EJ, Park HS, Yim H, Kang Y, et al. Identification of cytokeratin 18 as a bronchial epithelial autoantigen associated with nonallergic asthma. Am J Respir Crit Care Med. 2002 Jun 1;165(11):1536-9. https://doi.org/10.1164/rccm.200201-009OC PMID:12045129

22. Dobashi N, Fujita J, Murota M, Ohtsuki Y, Yamadori I, Yoshinouchi T, et al. Elevation of anti-cytokeratin 18 antibody and circulating cytokeratin 18: anti-cytokeratin 18 antibody immune complexes in sera of patients with idiopathic pulmonary fibrosis. Lung. 2000;178:171-9. https://doi.org/10.1007/s004080000020

23. Gao ML, Chen L, Li YF, Xue XC, Chen L, Wang LN, Shah W, Kong Y. Synergistic increa se of oxidative stress and tumor markers in PAH-exposed workers. Asian Pac J Cancer Prev. 2014;15(17):7105-12. https://doi.org/10.7314/apjcp.2014.15.17.7105 PMID:25227798

24. Khan M, Muhmood K, Noureen S, Mahmood HZ, Amir-Ud-Din R. Epidemiology of respiratory diseases and associated factors a mong female textile workers in Pakistan. Int J Occup Saf Ergon. 2020 Jun 30:1-15. https://doi.org/10.1080/10803548.2020.175197 3 PMID:32602797 